\title{
Evaluation of the Use of Concept Cartoon Activities in Teaching the Translation Concept from Students' Perspectives
}

\author{
Elif Ertem Akbaş ${ }^{1}$ Esra Kılıç ${ }^{2}$ \\ ${ }^{1}$ Assistant Professor, Van Yuzuncu Yil University, Van, Turkey \\ ${ }^{2}$ Mathematics Teacher, Ministry of Education, Van, Turkey \\ Correspondence: Elif Ertem Akbaş, Assistant Professor, Van Yuzuncu Yil University, Van, Turkey.
}

Received: September 22, 2019

Accepted: October 16, 2019 Online Published: October 21, 2019

doi:10.11114/jets.v8i1.4534

URL: https://doi.org/10.11114/jets.v8i1.4534

\begin{abstract}
The present study aimed to examine students' views about the evaluation of teaching via concept cartoon activities related to the translation concept within the scope of the sub-learning domain of $8^{\text {th }}$ grade transformation geometry. The study was carried out using the case study method, which is based on the qualitative approach. The participants in the study were $408^{\text {th }}$ grade students ( 25 female and 16 male) from two different classes of a state secondary school located in the Eastern Anatolia in Turkey. The application process in the study was conducted in one week, and the interviews held following the application process lasted three days. As the data collection tool, a semi-structured five-item interview form was used. The interviews were audio recorded, and they were transcribed and analyzed using the content analysis method. Following this, the students' responses to each interview question were coded. Codings were obtained using an inductive analysis method. The research results revealed that the concept cartoon activities provided the students with a wide variety of benefits (instructive, entertaining, motivating, mental development and so on) and that the students had positive views about the use of cartoon activities in lessons. Considering the analysis results and the students' views, the educational and methodological aspects of the study were discussed.
\end{abstract}

Keywords: concept cartoon activities, mathematics teaching, translation concept, $8^{\text {th }}$ grade students

\section{Introduction}

In the $21^{\text {st }}$ century, as a result of the rapid on-going developments, today's societies need individuals who have life-long learning skills, who keep up with the requirements of the era and follow the developments and who can produce information besides being a conscious consumer of information (Akkoyunlu \& Kurbanoğlu, 2003). In this respect, it is important to train individuals who can follow and keep up with the developments as well as who can think and produce their own strategies to solve the problems they face in their daily lives. Obviously, teachers are responsible for the process of training such individuals. Therefore, the teachers who will manage this process should not only know mathematics well, which is an important tool used to solve daily life problems (Baykul, 2014), but also train individuals who have the ability to use mathematics (Doruk \& Umay, 2011). All these needs can be met if teachers put forward different strategies to support learning in different learning environments. In this respect, in order to meet the needs and expectations and to train individuals who know, understand and interpret mathematics, it is apparently important to create effective learning environments and to use activities for permanent learning in these environments (Olkun \& Uçar, 2009).

Since students fail to understand mathematics well due to its abstract nature, it is considered to be one of the most difficult fields to learn (Beurk, 1982). This situation causes most students to fear the course of mathematics during their school years and to perceive the course to be difficult to learn (Başar, Ünal \& Yalçın, 2002; Ertem Akbaş, 2018; Dursun \& Dede, 2004; Sedighian, 1997; Yunus \& Ali, 2009). Mathematics, which exists in almost all areas of our lives, involves abstract thinking skills. This is actually one of the factors that makes learning mathematics difficult (Ertem Akbaş, 2018; Umay, 1996; Yunus \& Ali, 2009). One of the subjects in mathematics which we frequently face in our daily lives and which requires abstract thinking skills is the subject of symmetry. The subject of symmetry, which is regarded as a specific learning domain in geometry, could be associated with daily life in general, yet many students find this subject difficult to understand and apply, and they consider it to be a subject that needs special focus (Faggiano, Montone \& Mariotti, 2018; Grafton, 2011; Jittam, Ruenwongsa \& Panijpan, 2008; Özyaşar, 2013; Yavuzsoy, Köse \& 
Özdaş, 2009). Yavuzsoy, Köse \& Özdaş (2009) and Özyaşar (2013) point out that students have difficulty concretizing and perceiving the subject of symmetry. Furthermore, students can answer geometry-related questions which require imitating in mathematics or which involves a certain pattern, but they have difficulty in identifying the hierarchical relationships between geometric figures (Güler, 2016). This difficulty causes students to develop a negative viewpoint about the subject of symmetry. According to Güler \& Altun (2018), the factors that cause students to experience difficulty in learning geometry-related subjects include students' considering only the prototypes of geometric figures, their failure to use the mathematical language and their avoidance of associating geometry-related concepts with daily life.

The goals of mathematics teaching, which is based on the use of the mathematical language, include teaching students the mathematical knowledge, skills and concepts that they will need in their daily lives as well as in their education process (MNE, 2018). In this respect, it is important to examine the learning domains of the subject of symmetry included the mathematics curriculum and to allow students to understand and learn the related concepts. This importance makes it necessary to achieve the outcomes related to teaching the concepts in "spatial relations" and "transformation geometry", which are sub-learning domains of the learning domain of "geometry and measurement" in the mathematics curriculum. For this purpose, the concepts in geometry should first be perceived intuitively and then mathematized to facilitate understanding (Baki, 2018). In this case, when the goal of mathematics teaching is associated with geometry, there appears the purpose of allowing students not only to acquire the mathematical knowledge and skills required by daily life (Altun, 2008) but also to develop their thinking and reasoning processes in relation to figures in daily life (Ali \& Reid, 2012; Van de Walle, Karp\& Bay-Williams, 2010). All these purposes have encouraged researchers to conduct studies on how to teach mathematics effectively, what qualities a mathematics teacher should have and how to teach the contents determined within the scope of the mathematics curriculum. Therefore, mathematics teachers should conduct studies on effective mathematics teaching (Hong, Hwang, Lu, Cheng, Lee \& Lin, 2009; Kabaca, Çontay \& İymen, 2011; Kula \& Erdem, 2005) and with effective mathematics teachers (Ertem, Cancan \& Kılıç, 2019; Yunus \& Ali, 2009) to change students' negative attitudes towards mathematics, to make them love mathematics and to help them achieve effective learning. Furthermore, in literature, there is an emphasis on the importance of selecting appropriate methods and techniques to achieve the goals of the contents determined in the mathematics curriculum (Pesen, 2008). According to De Holton, Ahmed, Williams \& Hill (2001) and Soylu (2001), teaching mathematics with game-based activities is an effective method for changing students' viewpoints about mathematics and for helping them acquire the mathematical thinking skills. Similarly, one of the methods used to develop students' problem solving skills and to encourage them to take an active role in lessons is the visual tool of concept cartoons (Balım, İnel \& Evrekli, 2008).

Concept cartoons are drawings in the form of interesting and thought-provoking cartoons in which each cartoon character states a different view about a daily life event (Keogh and Naylor, 1999; Martinez, 2004). Considering the fact that mathematical concepts (or information) are abstract and that it is difficult to observe these concepts in real life and to provide related examples while teaching these concepts, concept cartoons are thought to be effective in drawing individuals' attention to mathematics and in developing a positive viewpoint about it. In addition, concept cartoons are used to have students question their knowledge in an entertaining manner (Keogh \& Naylor, 1999). Yoong (2001) points out that including humour in mathematics will make mathematics easy and meaningful and help adapt it into daily life, which will in turn increase learners' interest in mathematics and facilitate remembering. The subject of symmetry in the learning domain of "geometry and measurement" in the mathematics curriculum has an important place in daily life. For this reason, use of concept cartoon activities is thought to increase permanency in learning the concept of "translation" taught within the scope of "transformation geometry", which is a sub-learning domain of the learning domain of "geometry and measurement". Moreover, students' views are obviously regarded as one of important components for determining the effectiveness of concept cartoons, which lead to students' active participation in lessons and which encourage them to produce new information through discussions. Therefore, for the evaluation of concept cartoon activities used for teaching the translation concept, it is important to take the viewpoints of students, who are active participants of the education process. According to related literature, in Turkey, there is a limited amount of research carried out to determine students' views about the use of concept cartoon activities specifically for teaching the translation concept and generally for teaching mathematics. In this respect, the present study is considered to be important and to contribute to the field. In line with this importance, this study aimed to evaluate the use of concept cartoon activities for teaching the translation concept from the perspectives of students (Balım, İnel \& Evrekli, 2008).

Accordingly, this study focused on the translation concept within the scope of "transformation geometry", which is a sub-learning domain of the 8th grade learning domain of "geometry and measurement". The purpose was to examine the students' views about the evaluation of teaching with concept cartoon activities regarding the following outcome related to the translation concept: "Students can draw the images of points, line segments and other figures as a 
consequence of translation". In line with this purpose, the study tried to find answers to the question of "What are students'views about the use of concept cartoon activities for teaching the translation concept?"

\subsection{The place of the Sub-learning Domain of "Transformation Geometry" in the Mathematics Curriculum in Turkey}

In the study, the focus was on the concept of "translation", one of the concepts of symmetry, and the concept is taught within the scope of the sub-learning domain of "transformation geometry" in the learning domain of "geometry and measurement" (for $5^{\text {th }}$ to $8^{\text {th }}$ grade students) as well as within the scope of the sub-learning domain of "spatial relations" in the learning domain of "geometry" in the mathematics curriculum in Turkey (MNE, 2018). In this respect, the concept of "translation" is included in the sub-learning domain of "transformation geometry" in the mathematics curriculum for $8^{\text {th }}$ grade students. Table 1 presents the class grades, the target concepts, the learning domains and the sub-learning domains covered in the mathematics curriculum in Turkey.

Table 1. Place of the subject of symmetry in the mathematics curriculum in Turkey

\begin{tabular}{|c|c|c|c|c|c|c|c|c|c|c|}
\hline \multirow{2}{*}{ Learning Domain } & \multirow{2}{*}{$\begin{array}{l}\text { Sub-Learning } \\
\text { Domain }\end{array}$} & \multirow{2}{*}{ Concepts } & \multicolumn{8}{|c|}{ Class Grades } \\
\hline & & & 1 & 2 & 3 & 4 & 5 & 6 & 7 & 8 \\
\hline \multirow{3}{*}{ Geometry } & \multirow{3}{*}{ Spatial relations } & symmetric figures & & $\mathrm{X}$ & & & & & & \\
\hline & & symmetry line & & & $\mathrm{X}$ & & & & & \\
\hline & & mirror symmetry & & & & $\mathrm{X}$ & & & & \\
\hline $\begin{array}{l}\text { Geometry } \\
\text { measurement }\end{array}$ & $\begin{array}{l}\text { Transformation } \\
\text { geometry }\end{array}$ & $\begin{array}{l}\text { reflection, translation, image, } \\
\text { symmetry line }\end{array}$ & & & & & & & & $\mathrm{X}$ \\
\hline
\end{tabular}

According to Table 1, students are introduced to symmetry for the first time in the $2^{\text {nd }}$ class grade within the scope of the outcomes of the concept of "symmetric figures" in the sub-learning domain of "spatial relations" in the learning domain of "geometry". This is followed by such outcomes as finding out more than one symmetric line of figures like square and rectangle in the $3^{\text {rd }}$ grade and explaining symmetry via geometric structures and models and drawing the symmetry lines in $4^{\text {th }}$ grade. Next, in the $8^{\text {th }}$ grade, students meet important concepts and applications of symmetry like "reflection, translation, image and symmetry line" in the sub-learning domain of "transformation geometry" in the learning domain of "geometry and measurement". In addition, the $8^{\text {th }}$ grade also includes the outcomes related to translation and reflection transformations (Baki, 2018; MNE, 2018). Accordingly, it could be stated that students have background knowledge about the subject of symmetry yet face the concept of "translation" for the first time when they become $8^{\text {th }}$ grade students. Therefore, in the present study, the concept cartoons designed in relation to the concept of "translation" were applied to $8^{\text {th }}$ grade students as appropriate to the related outcome in their education process. Next, the views of the students participating in the study about the concept cartoon activities related to the translation concept were examined.

\subsection{Concept Cartoons and Mathematics Teaching}

Concept cartoons are drawings which include cartoons related to daily life events and provide an alternative viewpoint for scientific subjects (Keogh \& Naylor, 1999; Martinez, 2004). The characters in these drawings are interesting and amazing, and they encourage individuals to discuss the related subject (Keogh, Naylor \& Wilson, 1998). Concept cartoons used in an education process have a structurally different format when compared to that of that of popular cartoons, and they are used to have students question their knowledge in an entertaining manner though they do not include any humorous and exaggerated elements (Keogh \& Naylor, 1999). Also, these concept cartoons aim to start a discussion regarding a concept, a case or an event and to encourage individuals to question the target information (Keogh \& Naylor, 2000). Therefore, concept cartoons allow students to create an alternative viewpoint, to develop their cognitive skills and to increase their interest and motivation (Keogh \& Naylor, 1999; Long \& Marson, 2003).

Considering the fact that creating a discussion environment in teaching mathematics has an important place in helping students understand the subject (Ylldirm, 1996), it could be stated that it is important to use concept cartoons in the process of teaching mathematics. Furthermore, when the above-mentioned features of cartoons are taken into account, it is thought that they will allow decreasing students' anxiety about mathematics, making them love mathematics and helping them develop a positive attitude towards mathematics. However, when the related literature is examined, it is seen that a great majority of studies focused on science teaching (Yıldırım, 1996). On the other hand, concept cartoons can also be used in teaching mathematics. In this way, use of concept cartoons appropriate to the subject, the concepts and the methodology in teaching mathematics is believed to develop students' mathematical thinking skills. In line with this thought, the present study is considered to be important as it aimed to determine students' views about the use of concept cartoon activities in teaching mathematics in general terms and in teaching the concept of "translation" in specific terms. 


\section{Methodology}

This part presents the method, participants, validity and reliability of the study, data collection tool, the application process-procedure and data analysis.

\subsection{Research Model}

In the study, based on the students' responses to the concept cartoon activities and on the interviews held with them following the activities, the purpose was to determine their views about the use of concept cartoon activities in teaching the translation concept. In line with this purpose, the qualitative research method was used in the study. Qualitative studies are popular among researchers since these studies allow revealing participants' understandings, thoughts and emotions in a realistic and holistic manner in their natural environments (Yıldırım \& Şimşek, 2013). Moreover, in qualitative studies, the research data collected via data collection tools like interviews are arranged and categorized to obtain themes, and eventually, this whole process is reported (Özdemir, 2010). In the present study, the case study method, which is based on the qualitative approach, was used. The case study method allows in-depth examination of a problem by focusing on a certain situation, subject, individual or groups and provides the opportunity to explain the systematic relationships between the collected data within the reason-result framework (Cohen \& Manion, 1998). In this respect, in the present study, the case study method, one of qualitative research approaches, was used not only because $8^{\text {th }}$ grade students' views about the use of concept cartoon activities in teaching the translation concept, one of subjects in transformation geometry, were taken into account as the specific case in the study but also because the number of the participants was low.

\subsection{Participants}

The study was carried out with $408^{\text {th }}$ grade students (24 female, 16 male) from two different classes of a state secondary school in the East of Turkey in the Spring Term of the academic year of 2018-2019. While determining the research sample, the purposeful sampling method, which allows conducting in-depth investigation within the scope of the sample in line with the research problem (Büyüköztürk, Çakmak Kılıç, Akgün, Karadeniz \& Demirel, 2008). As the purpose of such studies as this one is not to generalize the results, special attention was paid to the holistic and in-depth examination of the data collected from the research sample. Furthermore, for the selection of the research sample, the students' levels of readiness for the translation concept within the scope of transformation geometry were taken into account. The number of the students to be interviewed was determined in a way to obtain the data that the researchers would need for the study (Lincoln \& Guba, 1990). In this respect, following the applications, interviews started with the students selected randomly among all the students. By the time the needed data were obtained, a total of 17 students (10 female, 7 male) had been interviewed. The students participated in the interviews on voluntary basis, and for ethical purposes, they were coded as S1, S2, .., S17.

\subsection{Validity and Reliability of the Study}

The validity and reliability of qualitative studies should be ensured by taking transferability, credibility, consistency and confirmability into consideration (Denzin \& Lincoln, 1994). Therefore, first, the concept cartoon activities to be used in the application phase of the study were prepared in drafts. The cartoons found in the draft activities were examined by an art trainer expert in the field of visual arts and graphic design and by a teacher of visual arts who was a post graduate student in this field for credibility and visual consistency; by a faculty member expert in the related field for transferability and adaptability into Turkish; and by two faculty members expert in the field of mathematics teaching and by one mathematics teacher who was a postgraduate student in this field for content validity. Following this, considering the corrections suggested by the experts, the draft activities were finalized, and the finalized version was applied to the participants. At the end of the application process, in order to ensure the validity and reliability of the study, two faculty members expert in the field were asked for their views in relation to the analysis of the data collected via the interviews. Also, those who participated in the interviews were selected among the volunteering students, and the students' views were presented with direct quotations. The data collected were audio-recorded for the confirmability of the study. For the purpose of ensuring the validity of the data collected via the interviews, preliminary interviews were held to reveal whether the $8^{\text {th }}$ grade students participating in the study had background knowledge about the concept of symmetry.

\subsection{Data Collection Tool}

In the study, the semi-structured interview technique was used. In this technique, the researcher prepares an interview form which includes the questions he or she has planned to direct to the participants, and depending on the flow of the interview, the researcher can ask additional questions during or after the process to allow the participants elaborate their responses (Yıldırım \& Şimşek, 2013). In the present study, a semi-structured interview form was prepared including eight open-ended questions. In order to ensure the content validity of the questions found in the semi-structured 
interview form, three experts who had a doctorate degree in the field of mathematics teaching and who had conducted qualitative studies before were asked for their views. In line with the experts' views, the necessary corrections were done in the interview questions, and three questions which were thought to be specific were excluded from the interview form. Also, some other students, who were at the same age as the students to be interviewed were asked to read the interview questions to see whether the questions were comprehensible or not. The finalized questions in the semi-structured interview form to be applied to the students at the end of the application process were as follows:

1. Have you ever seen concept cartoon activities before?

2. What did you think when you first saw the concept cartoon activities in teaching the translation concept?

3. What features of the concept cartoon activities influenced you most? What did you find most interesting about them?

4. What are your views about the use of concept cartoon activities in the course of mathematics?

5. Would you use concept cartoon activities in other subjects of mathematics or in other courses? Why?

\subsection{Application Process-Procedure}

Within the scope of the study, the application process was conducted in five class hours in one week (each class hour lasts 40 minutes), and the post-application interviews lasted three days out of class hours (an interview with each student took about 10 minutes). The target outcomes were parallel to the curriculum suggested by the Ministry of National Education (MNE, 2018). In this respect, in the application phase of the study, the students carried out two activities designed with concept cartoons regarding the translation concept within the scope of the sub-learning domain of transformation geometry in accordance with the $8^{\text {th }}$ grade outcomes. In the preparation phase of the activities designed and applied by the researchers, the cartoons used in the activities were drawn in a way to be colourful, interesting and related to daily life. Moreover, the activities were prepared and applied in a way to appeal to the students' cognitive levels, and the activities were thus clear and comprehensible enough to make the students think. The activities covered the sub-outcomes of the first outcome of the concept of translation: "can draw the images of points, line segments and other figures as a consequence of translation" (MNE, 2018). These outcomes were as follows: "in translation, students recognize that each point in the figure moves in the same direction and that the figure and the related image are similar" for the first activity (Moving the car, See Figure 1, Figure 2), and "students study on the coordinate system on squared or dotted paper" for the second activity (Pecman Game). Within the scope of the study, for the reliability of the data, the application process was video-recorded by the researcher. Table 2 summarizes the procedures related to the application phases of.

Table 2. Procedures related to the application phases in the study

\begin{tabular}{|c|c|c|}
\hline Application Phases & Procedure & Duration \\
\hline $1^{\text {st }}$ Class Hour & $\begin{array}{l}\text { Activating students' preliminary knowledge about the outcome of "Students } \\
\text { can draw the images of points, line segments and other figures as a } \\
\text { consequence of translation", distributing the cartoon activity paper related to } \\
\text { "Moving the car" and discussing the cartoons in the activity }\end{array}$ & $40 \mathrm{~min}$. \\
\hline $2^{\text {nd }}$ Class Hour & $\begin{array}{l}\text { Student-centered application using the cartoon activity paper of "Moving the } \\
\text { car" distributed in relation to the sub-outcome of "In translation, students } \\
\text { recognize that each point in the figure moves in the same direction and that } \\
\text { the figure and the related image are similar" }\end{array}$ & $40 \mathrm{~min}$. \\
\hline $3^{\text {rd }}$ Class Hour & $\begin{array}{l}\text { Activating students" preliminary knowledge about the outcome of "Students } \\
\text { can draw the images of points, line segments and other figures as a } \\
\text { consequence of translation", distributing the cartoon activity paper related to } \\
\text { "Pecman Game" and discussing the cartoons in the activity }\end{array}$ & $40 \mathrm{~min}$. \\
\hline $4^{\text {th }}$ Class Hour & $\begin{array}{l}\text { Student-centered application using the cartoon activity paper of "Pecman } \\
\text { Game" distributed in relation to the sub-outcome of "Students study on the } \\
\text { coordinate system on squared or dotted paper" }\end{array}$ & $40 \mathrm{~min}$. \\
\hline $5^{\text {th }}$ Class Hour & $\begin{array}{l}\text { General evaluation regarding the translation concept taught with the concept } \\
\text { cartoon activities, and determining the volunteering students for the } \\
\text { semi-structured interviews }\end{array}$ & $40 \mathrm{~min}$. \\
\hline $\begin{array}{l}\text { Out of Class } \\
\text { (3 days) }\end{array}$ & $\begin{array}{l}\text { After the application process, holding the semi-structured interviews with } 17 \\
\text { volunteering students ( } 10 \text { minutes on average for each student) }\end{array}$ & $170 \mathrm{~min}$. \\
\hline $\begin{array}{l}5 \text { Class Hours }+ \\
\text { Out of Class } \\
(1 \text { week }+3 \text { days }) \\
\end{array}$ & Total & 370 min. \\
\hline
\end{tabular}


Figure 1 presents the concept cartoon activity of "Moving the car" designed in relation to the sub-outcome of "In translation, students recognize that each point in the figure moves in the same direction and that the figure and the related image are similar", and Figure 2 shows the questions found in the activity.

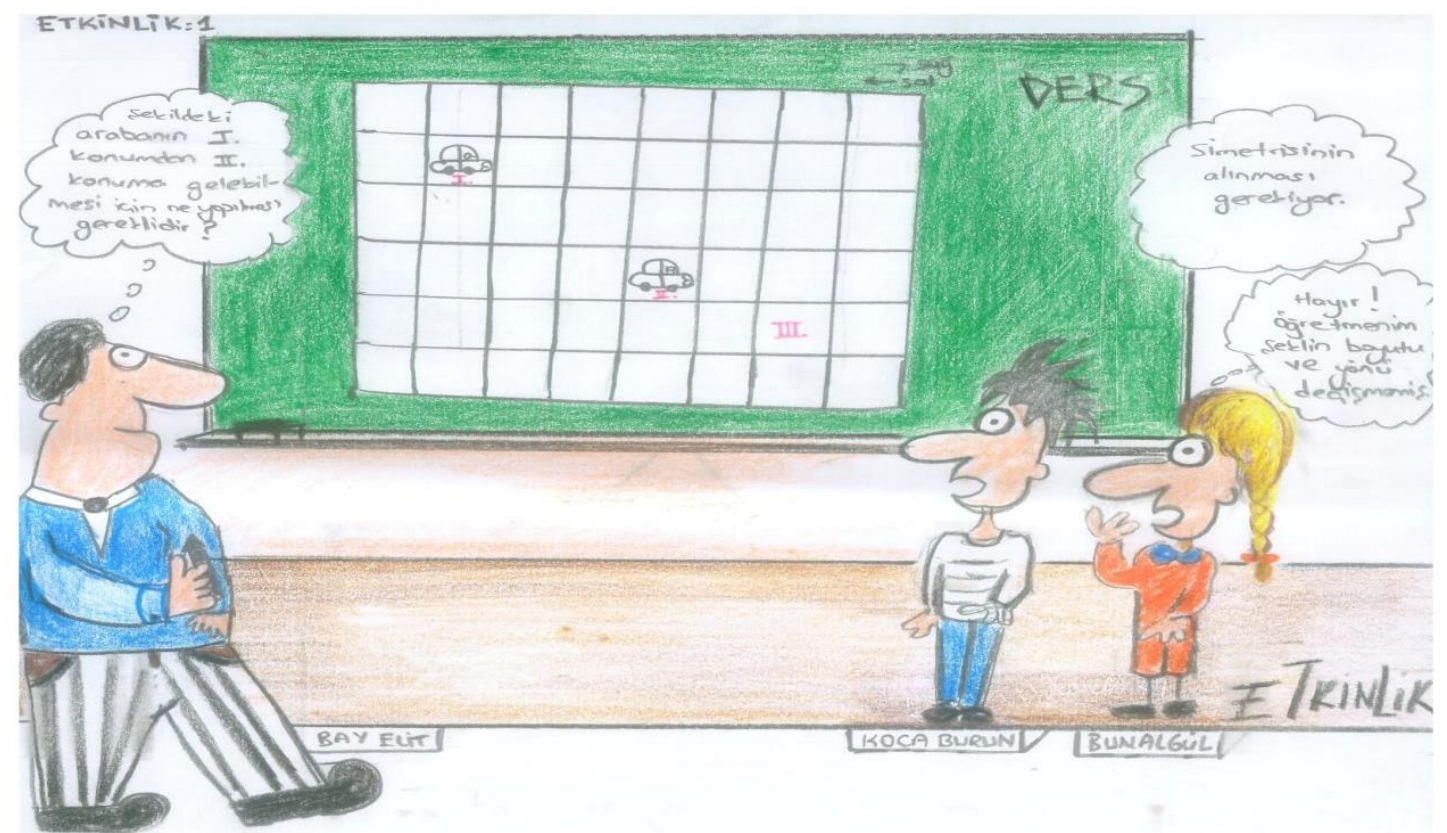

Figure 1. The cartoon related to the activity of "Moving the car"

Activity 1. (English translation for figure 1)

Mr. Elit (meaning "elite"): "What should be done to move the car from Position I to Position II?"

Koca Burun (meaning "big nose"): "Its symmetry should be taken"

Bunalgul (meaning "boring girl"): "No! Sir, there is no change in the size or direction of the figure"

In Figure 1, in response to the question of what should be done to move the car from Position 1 to Position II in the squared plane formed on the board by Mr. Elit, Big Nose only states that its symmetry should be drawn, and Bunalgül objects to Big Nose's answer and states that there is no change in the size or direction of the figure. The purpose of this activity was first to remind students of the procedure of translation, which requires students to move a figure in the desired direction, and then to make students recognize that each point on the car in Position I moves in the same direction and that it is similar to its image in Position II. For this purpose, the questions in Figure 2 were directed at the end of the activity.

Karikatüre göre;

A)Koca Burun, Bay Elit' in sorusunu sence doğru mu yanlış mı cevaplamıştır?

B)Koca Burunun yerin de olsaydın sen nasıl cevap verirdin? Nedeni ile açıklar mısın?

C)Bunalgül, Bay Elit' in sorusunu sence doğru mu yanlış mı cevaplamıştır?

D)Bunalgül' ün yerinde sen olsaydın nasıl cevap verirdin? Nedeni ile açıklar mısın?

E)Peki Bay Elit şekilde ki arabanın III. Konumda ki duruma gelmesi için ne yapılması gerektiğini sorsaydı nasıl cevaplardın? Nedeni ile açıklar mısın?

Figure 2. The questions in the activity of "Moving the car" 
According to the cartoon; (English translation for figure 1)

A) Did Big Nose correctly or incorrectly answer the question directed by Mr. Elit?

B) If you were Big Nose, how would you answer the question? Why? Explain.

C) Did Bunagul correctly or incorrectly answer the question directed by Mr. Elit?

D) If you were Bunagul, how would you answer the question? Why? Explain.

E) If Mr. Elit asked what should be done to move the car to Position III, how would you answer such a question? Why? Explain.

As can be seen in Figure 2, the questions based on the statements in the cartoon were directed to the students at the end of the activity of "Moving the car". The purpose of these questions was to allow the students to examine and interpret the responses of Big Nose and Bunagul to Mr. Elit. In this way, the students were provided with the opportunity to give conceptual meaning to the responses of Big Nose and Bunagul and to achieve the outcome of "In translation, students recognize that each point in the figure moves in the same direction and that the figure and the related image are similar".

\subsection{Data Analysis}

For the analysis of the data, first, the audio-recorded semi-structured interviews were transcribed. The transcribed data were examined using the content analysis method. Content analysis allows gathering similar data within the framework of certain concepts and themes to let readers understand and interpret the data (Büyüköztürk et al., 2008). Next, the responses given to each interview question were analyzed, and the data obtained were coded. As this procedure of coding done by the researchers did not include a conceptual structure to guide the coding process, the codings were done using the inductive analysis method (Strauss \& Corbin, 1990). Following the coding process, some of the data obtained were examined and recoded by two faculty members experienced in the field of qualitative research. Of all the data, 20\% of them were determined on random basis and given to the coders (Forbes, 2011), and they were asked to re-code these data in accordance with the code-definition table. In order to ensure the reliability of the qualitative analysis, the codings done by the researchers and by the two coders were calculated using the formula put forward by Miles \& Huberman (1994) (Reliability =Agreement / Agreement + Disagreement). When the agreement in the codings within the scope of this formula were examined, it was seen that for all the codes, the percentage of agreement was 0.82 between the researchers and the first coder and 0.86 between the researchers and the second coder. As for the average agreement between the researchers and the two coders, it was found to be 0.84 . For the coding reliability of researchers, it is reported that the percentage of agreement should be over 70\% (Miles \& Huberman, 1994). Next, the difference between the codings was evaluated on the basis of consensus, and the researchers reached an agreement. The codings that the researchers agreed on were categorized within the scope of the data obtained via the semi-structured interview questions. The data were presented in tables including the codings related to the categories, student codes and frequencies to facilitate understanding. In addition, within the scope of the reliability of the analysis, direct quotations from the students' responses were provided to put forward the reasoning for the codings. In relation to the presentation of the data, the criteria of "involving different views", "being explanatory" and "having variety" were taken into account for the selection of the quotations (Bümen, Ünver \& Başbay, 2010).

\section{Findings / Results}

Within the scope of the semi-structured interview questions prepared by the researcher, this part presents the codes obtained as a result of the content analysis of the data collected via the semi-structured interviews held with the students. The codes obtained based on the students' responses to each question, the frequency values related to the codes and the student codes are presented in tables.

First, the students were asked the question of "Have you ever seen concept cartoon activities before?", and the student codes can be seen in Table 3.

Table 3. The students' views about whether they had ever seen concept cartoon activities before

\begin{tabular}{lll}
\hline Codes & f & Student Codes \\
\hline No & 12 & S1, S3, S6, S7, S8, S9, S11, S12, S13, S14, S16, S17 \\
\hline Yes & 5 & S2, S4, S5, S10, S15 \\
\hline
\end{tabular}

According to Table 3, in relation to the question of "Have you ever seen concept cartoon activities before?", most of the students $(\mathrm{f}=12)$ reported that they had never seen any concept cartoon activities before, and some of them ( $\mathrm{f}=5)$ stated that they had. The data obtained via the interviews revealed that a great majority of the students saw concept cartoon activities for the first time thanks to the application in the lesson. Below are some of the students' views. 


\section{S3: No, I have never seen such a lesson before.}

S6: I haven't seen an activity like this before. This is the first time I have seen one in this lesson.

S9: I have seen them in cartoon books and test books.

As the second question, "What did you think when you first saw the concept cartoon activities in teaching the translation concept?" was directed to the students. Table 4 presents the student codes.

Table 4. Students' views about what they thought when they met the concept cartoon activities

\begin{tabular}{lcll}
\hline Codes & $\mathbf{f}^{*}$ & Student Codes \\
\hline It drew my attention/interest & & 13 & S1, S2, S5, S6, S7, S9, S10, S11, S13, S14, S15, S16, S17 \\
\hline $\begin{array}{l}\text { I thought it would } \\
\text { entertaining. }\end{array}$ & be & 11 & S1, S2, S3, S5, S8, S10, S11, S12, S14, S16, S17 \\
$\begin{array}{l}\text { Taking an active role in the } \\
\text { lesson }\end{array}$ & 8 & S4, S5, S6, S7, S8, S12, S13, S14 \\
\hline How will we do that activity? & 6 & S3, S4, S9, S11, S13, S15 \\
\hline
\end{tabular}

* Some of the students participating in the study reported more than one view.

When the students" views about the question of "What did you think when you first saw the concept cartoon activities in teaching the translation concept?" were examined, it was seen that the students found the characters most interesting when they first saw the concept cartoon activities $(\mathrm{f}=13)$ and that the lessons to be taught with the cartoon characters would be entertaining ( $\mathrm{f}=11$ ). Also, the students wanted to take an active role in the lessons in which the concept cartoon activities were used ( $\mathrm{f}=8)$, and they thought about how to respond to the questions in the cartoon activities $(\mathrm{f}=6)$. The data collected via the interviews revealed that the concept cartoon activities drew most of the students' attention and increased their interest in the lesson. Below are some of the students' views about this question:

S4: How would we solve it? How would I take part in the lesson? These questions came into my mind at first.

S10: When I first saw the drawings, I was very curious about them, and I thought the lesson would be quite entertaining.

S11: I was quite interested, and I thought it would be funny. I started wondering whether I would be able to move the car to Position II.

As the third question, "What features of the concept cartoon activities influenced you most? What did you find most interesting about them?"was directed to the students. Table 5 shows the student codes.

Table 5. Students' views about the attention-drawing features of the concept cartoon activities

\begin{tabular}{lll}
\hline Codes & $\mathbf{f}^{*}$ & Student Codes \\
\hline Memorable & 11 & S2, S4, S5, S7, S8, S9, S12, S13, S14, S16, S17 \\
\hline Interesting & 10 & S1, S3, S5, S6, S7, S10, S11, S14, S15, S17 \\
\hline It was colourful with drawings & 8 & S2, S3, S8, S9, S10, S14, S15, S16 \\
\hline $\begin{array}{l}\text { It included dialogues and } \\
\text { character names }\end{array}$ & 6 & S4, S8, S11, S12, S14, S15 \\
\hline
\end{tabular}

* Some of the students participating in the study reported more than one view.

When Table 5 was examined, it was seen that in relation to the question of "What features of the concept cartoon activities influenced you most? What did you find most interesting about them?", the students mostly reported the concept cartoon activities to be memorable ( $\mathrm{f}=11)$ and interesting $(\mathrm{f}=10)$. In addition, some of the students found the cartoons interesting as they were colourful with drawings $(\mathrm{f}=8)$ and with dialogues and character names ( $\mathrm{f}=6)$. The interviews also revealed that the concept cartoon activities had certain features influential on the students (drawing, colour, dialogue, character, name, memorability and so on). Below are some of the students' views about this question:

S5: The men in the drawings interested me, and they were quite memorable.

S8: It included drawings, and I liked this most. Also, the children in the cartoons were talking. Thanks to this, I can remember them all easily.

S12: In the activities, the children and the students were talking, and their names were very interesting. With these names and the talks, I can learn and remember more easily.

In the study, the fourth question directed to the students was "What are your views about the use of concept cartoon activities in the course of mathematics?". Table 6 presents the student codes. 
Table 6. Students' views about the use of concept cartoon activities used in the course of mathematics

\begin{tabular}{lcl}
\hline Codes & $\mathbf{f}^{*}$ & Student Codes \\
\hline $\begin{array}{l}\text { It made me like the lesson/it } \\
\text { was fun }\end{array}$ & 14 & S1, S3, S4, S6, S7, S9, S10, S11, S12, S13, S14, S15, S16, S17 \\
\hline It was related to daily life & 11 & S2, S3, S5, S7, S8, S10, S11, S13, S14, S16, S17 \\
\hline $\begin{array}{l}\text { It was deductive reinforcing } \\
\text { my knowledge }\end{array}$ & 10 & S1, S2, S4, S5, S9, S11, S12, S14, S15, S16 \\
\hline It arose my curiosity & 8 & S2, S4, S6, S8, S9, S12, S13, S17 \\
\hline Reasoning skills & 5 & S3, S7, S8, S12, S17 \\
\hline
\end{tabular}

* Some of the students participating in the study reported more than one view.

When the students" views about the question of "What are your views about the use of concept cartoon activities in the course of mathematics??" were examined, it was seen that the students mostly liked learning mathematics with the help of concept cartoon activities and enjoyed the lesson ( $\mathrm{f}=14)$; that they faced the questions in the activities out of class $(\mathrm{f}=11)$; and that they learned new information by reinforcing their previous knowledge $(\mathrm{f}=10)$. In addition, the students thought the characters in the concept cartoon activities arose their curiosity $(\mathrm{f}=8)$ and developed their reasoning skills thanks to the questions in the dialogues $(\mathrm{f}=5)$. The data collected via the interviews also revealed that use of concept cartoon activities in the course of mathematics had influence on the students' cognitive skills in their learning process such as thinking, reasoning and relating with daily life. Below are some of the students' views about this question:

S11: The lesson was very entertaining, and there were questions we could meet out of class. I mean I believe I understood the lesson unit of translation in mathematics better.

S12: I found the lesson very interesting, and I think I increased my previous knowledge. In this way, I learn more easily, and this makes me love the course of mathematics.

S17: The lesson was entertaining, and this way of teaching mathematics makes us like the course. Also, when look at the men and their talks in the cartoons, I wonder what will happen next. I mean we need to interpret them, and we need to think. We give answers in this way.

As for the last question directed to the students in the study, it was "Would you use concept cartoon activities in other subjects of mathematics or in other courses? Why?". Table 7 shows the student codes.

Table 7. Students' views about the use of concept cartoon activities in other subjects of mathematics or in other courses

\begin{tabular}{lll}
\hline Codes & $\mathbf{f}^{*}$ & Student Codes \\
\hline Entertaining & 13 & S2, S3, S4, S6, S8, S9, S10, S11, S12, S14, S15, S16, S17 \\
\hline Motivating & 11 & S2, S3, S5, S6, S8, S9, S10, S12, S13, S15, S16 \\
\hline Facilitating learning & 10 & S1, S4, S5, S7, S10, S11, S12, S14, S15, S17 \\
\hline $\begin{array}{l}\text { Being appropriate to cognitive } \\
\text { level, appealing to students }\end{array}$ & 7 & S2, S5, S7, S9, S11, S13, S16 \\
\hline
\end{tabular}

* Some of the students participating in the study reported more than one view.

According to Table 7, in relation to the question of "Would you use concept cartoon activities in other subjects of mathematics or in other courses? Why?", all the students wanted to use the concept cartoon activities. In addition, the students mostly reported that use of concept cartoon activities in other subjects of mathematics and in other courses besides the translation concept within the scope of the course of mathematics would make lessons more entertaining $(\mathrm{f}=13)$, motivate students in lessons ( $\mathrm{f}=11$ ) and facilitate learning $(\mathrm{f}=10)$. Moreover, some of the students $(\mathrm{f}=7)$ stated that concept cartoon activities should be used in other subjects of mathematics and in other courses since it was possible to prepare these activities as appropriate to students' interests and cognitive levels. Based on the data collected via the interviews, the students could be said to have positive views about the use of concept cartoon activities in other subjects of mathematics and in other courses if these activities were prepared in a way to appeal to students' interests and cognitive levels. Below are some of the students' views about this question:

S2: If these activities are used in other subjects of mathematics and in other courses, I think it will be very entertaining. When these activities are appropriate to our levels and when we like them, we will be more motivated for the lessons.

S7: To me, the activities were appropriate to our levels. Thus, I could learn more easily.

S12: I generally find mathematics boring, but these activities help us concentrate on the lesson. This is better, and we learn more easily. I just think so! 


\section{Discussion, Conclusion and Suggestions}

The purpose of the study was to examine $8^{\text {th }}$ grade students' views about concept cartoons using concept cartoon activities related to the outcomes of "In translation, students recognize that each point in the figure moves in the same direction and that the figure and the related image are similar" and "Students study on the coordinate system on squared or dotted paper", which were the sub-outcomes of "Students can draw the images of points, line segments and other figures as a consequence of translation" regarding the translation concept within the scope of the sub-learning domain of transformation geometry. In the study, the students' views revealed that such a teaching process was instructive, entertaining, motivating and thought-provoking. This result was thought to result from the fact that the concept cartoon activities were used in a humorous manner in teaching mathematics; that the activities developed the students' thinking skills; that the colourful visual characters in the cartoons students increased the students' motivation; and that the students were provided with an active learning environment. In relation to this, studies on cartoons demonstrate that they can be used for educational purposes (Keogh \& Naylor, 1999) especially in such areas as problem solving (Jones, 1987), developing thinking skills (De Fren, 1988), increasing motivation (Heintzmann, 1989), overcoming complexities (Naylor \& McMurdo, 1990), elaborating scientific information (Guttierrez \& Ogborn, 1992) and developing scientific thinking skills (Peacock, 1995).

The findings obtained via the students' views about the evaluation of concept cartoons used in the present study were gathered under five categories within the scope of the interview questions. The first category was related to whether the students had seen concept cartoon activities before, and the students' views revealed that most of them had never seen concept cartoon activities before. This situation could be associated with the fact that in the teaching process, teachers rarely, or never, use activities like concept cartoon activities as they generally use course books, test books, reading books and so on. Similarly, İnel, Balım \& Evrekli (2008) reported that $70 \%$ of the students had never seen concept cartoon activities before and that $30 \%$ of the students had seen concept cartoons in textbooks. In this respect, teachers could pay special attention to the selection of materials they will use in their mathematics lessons, and they could make more use of activities like concept cartoons, which will increase motivation and develop thinking skills.

In relation to the second category in the study, when the students' views about the use of concept cartoon activities in teaching the translation concept were examined, it was found that the especially the colourful characters and their names in the concept cartoon activities drew most of the students' attention and increased their interest in the course. Furthermore, it was seen that the students thought about how to respond to the questions in the activities, discussed with their friends and wanted to take an active role in the lesson with a decrease in their anxiety as they understood the translation concept with the help of concept cartoon activities. In one study, Torok, McMorris \& Lin (2004) point out that with the help of cartoons appropriate to the goals, humour has the potential to humanize, prove, refute, support, decrease the anxiety and make people think constantly. In this respect, the fact that in teaching the translation concept with the use of concept cartoon activities, the students discussed the questions in the activities with their friends and wanted to take an active role in lessons by decreasing their anxiety could be explained with the fact that the concept cartoon activities applied in the study were prepared in a way to serve the purpose.

In the third category in the study, when the students' views about the features of the concept cartoon activities that drew the students' attention were examined, it was seen that the basic features of the activities influential on the students were that the activities were memorable and interesting and that they included drawings and dialogues. This result could be explained with the fact that the drawings in the concept cartoon activities used in the study were colourful; that the names of the characters in the dialogues were interesting; and that the activities appealed to the students' cognitive levels. Similarly, Balım, İnel \& Evrekli (2008) found that colourful concept cartoons with drawings increased students' interest and entertained them.

When the students' views about the use of concept cartoon activities in mathematics were examined, it was seen that the activities applied in the study made the students love mathematics, resulted in their active participation in lessons and decreased their anxiety about mathematics. Moreover, the students' views revealed that the concept cartoon activities applied in the study developed students' skills in thinking, reasoning and associating with daily life. Similarly, Keogh \& Naylor (1999) and Martinez (2004) reported that each character in concept cartoons has a different view about a daily life phenomenon and that these cartoons include interesting and wonderful drawings. In this respect, the characters and the dialogues included in concept cartoon activities to be used in teaching mathematics should be selected attentively in a way to include humour and to develop students' thinking skills.

Lastly, when the students' views about the use of concept cartoon activities in other subjects of mathematics and in other courses were examined, it was seen that they reported positive views about the use of concept cartoon activities in teaching appropriate subjects and courses. Also, the students' views revealed that teaching a course with concept cartoons facilitated learning, increased motivation and made the lessons entertaining. Similarly, in some other studies examining students' 
views about concept cartoons (Başarmak \& Mahiroğlu, 2015; Ekici, Ekici \& Aydın, 2007), it was found that most students had positive views and enjoyed concept cartoons. In one study carried out in the field of mathematics, Erdağ (2011) reported that use of concept cartoons in the teaching process had positive influence on students' success. Similarly, Toh, Cheng, Ho, Jiang \& Lim (2017) put emphasis on the importance of use of concept cartoons in mathematics to develop students' learning and suggested using concept cartoons. In this respect, it could be stated that use of concept cartoon activities in appropriate learning domains with an appropriate teaching methods and strategies involving humour appropriate to the outcome supports the teaching process. In this respect, it is important to prepare effective concept cartoon activities. Therefore, the questions to be used in concept cartoon activities involving the question-and-answer method could be directed with the help of concept cartoons rather than directly by the teacher and/or students.

The findings obtained within the scope of the present study demonstrate that the students had positive views about concept cartoons applied in teaching the translation concept. Based on the results, use of concept cartoon activities in teaching secondary school mathematics cannot always be said to lead to positive views. However, it could be stated that use of concept cartoons in teaching mathematics in general terms and in teaching the concept of "translation" in specific terms have positive influence on students' views. Considering the fact that students commonly have anxiety about learning mathematics due to the abstract concepts (Ertem Akbaş, 2018) and that abstract concepts requiring abstract thinking are important (Moral, Köroğlu \& Çelik, 2004;Yunus \& Ali, 2009), concept cartoons prepared in a way to serve the purpose can be used as an effective teaching material in the education process.

\section{References}

Akkoyunlu, B., \& Kurbanoğlu, S. (2003). A study on teacher candidates' perceived information literacy self-efficacy and perceived computer self-efficacy. Hacettepe University Journal of Education, 24(24), 1-10.

Ali, A. A., \& Reid, N. (2012). Understanding mathematics: some key factors. European Journal of Educational Research, 1(3), 283-299. https://doi.org/10.12973/eu-jer.1.3.283

Altun, M. (2008). Secondary education (6th, 7th and 8th grades) teaching mathematics (5th Edition). Bursa: Aktiuel Publishing.

Baki, A. (2018). Knowledge of Teaching Mathematics. Ankara: Pegem Akademi. https://doi.org/10.14527/9786052410318

Balım, A. G., İnel, D., \& Evrekli, E. (2008). The effect of using concept cartoons on students' academic achievement and questioning learning skills perceptions in science teaching. Elementary Education Online, 7(1), 188-202.

Başar, M., Ünal, M., \& Yalçın, M. (2002). Causes of math fear starting with elementary school. V. National Science and $\begin{array}{lll}\text { Mathematics } & \text { Cducation } & \text { Congress, }\end{array}$ http://www.fedu.metu.edu.tr/ufbmek5/b_kitabi/PDF/Matematik/Bildiri/t212d 18.03.2019

Başarmak, U., \& Mahiroğlu, A. (2015). Student views on cartoon animation used in online learning environment. International Journal of Eurasia Social Sciences, 19(6), 234-253.

Baykul, Y. (2014). Statistics for social sciences: SPSS applied. Pegem Akademi.

Buerk, D. (1982). An experience with some able women who avoid mathematics. For the Learning of Mathematics, 3(2), 19-24.

Bümen, N. T., Ünver, G., \& Başbay, M. (2010). Examination of secondary education field teaching non-thesis master's program courses according to student views: The case of Ege University. Educational Sciences and Practice, 9(17), $41-62$.

Büyüköztürk, Ş., Çakmak Kılıç, E., Akgün, Ö. E., Karadeniz, Ş., \& Demirel, F. (2008). Scientific research methods (2nd Edition). Ankara: Pegem Akademi.

Cohen, L., \& Manion, L. (1998). Research methods in education (Fifth Edition). New York: Routledge.

De Holton, D., Ahmed, A., Williams, H., \& Hill, C. (2001). On the importance of mathematical play. International Journal of Mathematical Education in Science and Technology,32(3), 401-415. https://doi.org/10.1080/00207390118654

DeFren, M. (1988). Using cartoons to develop writing and thinking skills. The Social Studies, 79(5), 221-224. https://doi.org/10.1080/00220973.1945.11019921

Denzin, N. K., \& Lincoln, Y. S. (1994). Handbook of qualitative research. Thousand Oaks, CA, US: Sage Publications Inc.

Doruk, B. K., \& Umay, A. (2011). The effect of mathematical modeling on transferring mathematics into daily life. Hacettepe University Journal of Education, 41(41), 124-135. 
Dursun, Ş., \& Dede, Y. (2004). Factors affecting students 'success in mathematics in terms of mathematics teachers' opinions. Gazi University Journal of the Faculty of Education, 24(2), 217-230.

Ekici, F., Ekici, E., \& Aydin, F. (2007). Utility of Concept Cartoons in Diagnosing and Overcoming Misconceptions Related to Photosynthesis. International Journal of Environmental and Science Education, 2(4), 111-124.

Erdağ, S. (2011). The effect of mathematics teaching supported by concept cartoons on academic achievement and permanence in decimal fractions in 5 th grade mathematics lesson. (Doctoral dissertation). Dokuz Eylül University, İzmir.

Ertem, A. E., Cancan, M., \& Kiliç, E. (2019). Qualifications of an effective mathematics teacher from the perspectives of 5th to 8th grade secondary school students. Universal Journal of Educational Research, 7(2), 536-549. https://doi.org/10.13189/ujer.2019.070226

Ertem-Akbaş, E. (2018). Investigation of causes of mathematics fear and suggestions for solution starting with primary education in terms of teachers' opinions. International e-Journal of Educational Studies (IEJES), 2(3), 12-25.

Faggiano, E., Montone, A., \& Mariotti, M. A. (2018). Synergy between manipulative and digital artefacts: a teaching experiment on axial symmetry at primary school. International Journal of Mathematical Education in Science and Technology, 49(8), 1165-1180. https://doi.org/10.1080/0020739X.2018.1449908

Forbes, C. T. (2011). Preservice elementary teachers' adaptation of science curriculum materials for inquiry-based elementary science. Science Education, 95(5), 927-955. https://doi.org/10.1002/sce.20444

Grafton, A. K. (2011). Using role-playing game dice to teach the concepts of symmetry. Journal of Chemical Education, 88(9), 1281-1282. https://doi.org/10.1021/ed101023k

Güler, H. K. (2016). Determining, developing and evaluating the characteristics of an effective geometry course. (Unpublished doctoral dissertation). Uludağ University, Bursa.

Güler, H. K., \& Altun, M. (2018). Reflections of teachers' beliefs to their behaviours and the effective geometry lesson. Kastamonu Education Journal, 26(4), 1345-1357. https://doi.org/10.24106/kefdergi.443854

Gutierrez, R., \& Ogborn, J. (1992). A causal framework for analysing alternative conceptions. International Journal of Science Education, 14(2), 201-220. https://doi.org/10.1080/0950069920140208

Heitzmann, W. R. (1989). Historical cartoons: Opportunities to motivate and educate. Journal of the Middle States Council for the Social Studies, 11(1), 9-13.

Hong, J. C., Hwang, M. Y., Lu, C. H., Cheng, C. L., Lee, Y. C., \& Lin, C. L. (2009). Playfulness-based design in educational games: a perspective on an evolutionary contest game. Interactive Learning Environments, 17(1), 15-35. https://doi.org/10.1080/10494820701483615

Jittam, P., Ruenwongsa, P., \& Panijpan, B. (2008). Applying symmetries of common objects to help students understand stereoselectivity for apparently symmetric substrates. Bioscience Education, 12(1), 1-8. https://doi.org/10.3108/beej.12.6

Jones, D. (1987). Problem solving through cartoon drawing. Problem solving in primary schools. Oxford, UK: Basil Blackwell.

Kabaca, T., Çontay, E. G., \& İymen, E. (2011). From geometric representation to algebraic representation with dynamic mathematics software: parabola concept. Pamukkale University Faculty of Education Journal, 30(30), 101-110.

Keogh, B., \& Naylor, S. (1999). Concept cartoons, teaching and learning in science: an evaluation. International Journal of Science Education, 21(4), 431-446. https://doi.org/10.1080/095006999290642

Keogh, B., \& Naylor, S. (2000). Teaching \& learning in science using concept cartoons: why Dennis wants to stay in at playtime. Investigating: Australian Primary \& Junior Science Journal, 16(3), 10-14.

Keogh, B., Naylor, S., \& Wilson, C. (1998). Concept cartoons: a new perspective on physics education. Physics Education, 33(4), 219-224. https://doi.org/10.1088/0031-9120/33/4/009

Kula, A., \& Erdem, M. (2005). The effect of instructional computer games on the development of basic arithmetic processing skills. Hacettepe University Journal of Education, 29(29), 127-136.

Lincoln, Y. S., \& Guba, E. G. (1990). Judging the quality of case study reports. Internation Journal of Qualitative Studies in Education, 3(1), 53-59. https://doi.org/10.1080/0951839900030105

Long, S., \& Marson, K. (2003). Concept cartoons. Hands on Science, 19(3), 22-24.

Martinez, Y. M. (2004). Does the K-W-L reading strategy enhance student understanding in honors high school science classroom?. (Unpublished master's thesis). California State University, Fullerton. 
Miles, M. B., \& Huberman, A. M. (1994). Qualitative data analysis (Second Edition). London New Delhi: Sage Publication.

Ministry of National Education [MNE], (2018). Mathematics curriculum (Primary, Secondary, 1st, 2nd, 3rd, 4th, 5th, 6 th, 7 th and 8 th grades). Ankara.

Moralı, S., Köroğlu, H., \& Çelik, A. (2004). The attitudes of pre-service mathematics teachers of Buca Faculty of Education towards abstract mathematics course and common misconceptions. Gazi University Journal of the Faculty of Education, 24(1), 161-174.

Naylor, S., \& McMurdo, A. (1990). Supporting science in schools: udeas, activities and resources for professional development. Breakthrough Educational Publications.

Olkun, S., \& Uçar, Z. T. (2009). Activity based mathematics education in primary education (6th Edition). Ankara: Eğiten Kitap Publishing.

Özdemir, M. (2010). Qualitative data analysis: a study on the methodology problem in social sciences. Eskisehir Osmangazi University Journal of Social Sciencesi, 11(1), 323-343.

Özyaşar, A. (2013). Examining the transformation geometry abilities of 7th grade students in terms of various variables. (Master's thesis). Adiyaman University, Institute of Science, Adıyaman.

Peacock, M. (1995). Vitamin D receptor gene alleles and osteoporosis: a contrasting view. Journal of Bone and Mineral Research, 10(9), 1294-1297. https://doi.org/10.1002/jbmr.5650100904

Pesen, C. (2008). Learning difficulties and misconceptions of students in the representation of fractions on the number line. Journal of Inonu University Faculty of Education, 9(15), 157-168.

Sedighian, K. (1997). Challenge-driven learning: a model for children's multimedia mathematics learning environments. To appear in Proceedings of ED-MEDIA 97: World Conference on Educational Multimedia and Hypermedia, Calgary. Effect of Interface Style 357

Soylu, S. (2001). Autoignition modeling of natural gas for engine modeling programs: an experimental and modeling study. https://doi.org/10.31274/rtd-180813-13198

Strauss, A., \& Corbin, J. (1990). Basics of qualitative research (Vol. 15). Newbury Park, CA: Sage publications.

Toh, T. L., Cheng, L. P., Ho, S. Y., Jiang, H., \& Lim, K. M. (2017). Use of comics to enhance students' learning for the development of the twenty-first century competencies in the mathematics classroom. Asia Pacific Journal of Education, 37(4), 437-452. https://doi.org/10.1080/02188791.2017.1339344

Torok, S. E., McMorris, R. F., \& Lin, W. C. (2004). Is humor an appreciated teachıng tool? Perceptıons of professors' teaching styles and use of humor. College Teaching, 52(1), 14-20. https://doi.org/10.3200/CTCH.52.1.14-20

Umay, A. (1996). Mathematics education and measurement. Hacettepe University Journal of Education, 12(21), 145-149.

Van de Walle, J. A., Karp, K. S., \& Bay-Williams, J. M. (2010). Elementary and middle school mathematics: teaching developmentally (6th ed.). Boston: Pearson Education.

Yavuzsoy Köse, N., \& Özdaş, A. (2009). How do the fifth grade primary school students determine the line of symmetry in various geometrical shapes using cabri geometry software. Elementary Education Online, 8(1), 159-175.

Yıldırım, A., \& Şimşek, H. (2013). Qualitative research methods in social sciences (Expanded 9th Edition). Ankara: Seçkin Publishing.

Yıldırım, C. (1996). Mathematical thinking. İstanbul: Remzi Kitabevi Publishing.

Yoong, W. K. (2001). Mathematics cartoons and mathematics attitudes. Studies in Education, 6(6), 69-80.

Yunus, M., \& Ali, W. Z. W. (2009). Motivation in the learning of mathematics. European Journal of Social Sciences, 7(4), 93-101.

\section{Copyrights}

Copyright for this article is retained by the author(s), with first publication rights granted to the journal.

This is an open-access article distributed under the terms and conditions of the Creative Commons Attribution license which permits unrestricted use, distribution, and reproduction in any medium, provided the original work is properly cited. 